\title{
Data Activism: Reviving, Extending and Upgrading Critical Citizenship Education and Consumer Rights Movements
}

\author{
Ulaş Başar GEZGìN ${ }^{10}$
}

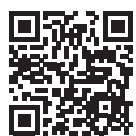

'Prof. Dr., Duy Tan University, Danang, Vietnam

ORCID: U.B.G. 0000-0002-6075-3501

Sorumlu yazar/Corresponding author:

Ulaş Başar Gezgin,

Duy Tan University, Danang, Vietnam

E-posta/E-mail: ulasbasar@gmail.com

Geliș tarihi/Received: 24.01.2019 Revizyon talebi/ Revision requested: 07.03.2019

Son revizyon teslimi/ Last revision received: 23.04 .2019

Kabul tarihi/Accepted: 25.04 .2019

Atıf/Citation: Gezgin, U. B. (2019). Data activism: Reviving, extending and upgrading critical citizenship education and consumer rights movements. Connectist: Istanbul University Journal of Communication Sciences, 56, 67-86.

https://doi.org/10.26650/CONNECTIST2018-0042

\begin{abstract}
Considering the omnipresence, omniscience and omnipotence of big data as the upgraded big brother, any resistance appears to be in vain. However, pessimistic accounts usually revolve on a model of a citizen as an individual. This atomized version of citizenship underestimates the power of citizens' social solidarity networks which can be as traditional as nuclear or extended families or as modern as professional organizations and rights movements. However, big data activism and these forms of resistance are rarely connected with each other. In this article, we discuss how to integrate already existing rights organizations with data activism. The following themes are explored for this purpose: Snowden revelations and evolution of state surveillance; digital activism and data activism; and data activism and critical citizenship education. The notion of 'critical' citizenship education rather than citizenship education is mobilized in our reflection, since the mainstream, official citizenship education agenda is far from addressing the negative effects of big data and associated double surveillance by the state and corporations. Contrary to a merely theoretical understanding of citizenship, data activism needs to unite its forces with already existing rights movements, including human rights and consumer rights movements as distinguishing components of a critical citizenship. The purpose of this article is to show in what ways citizenship education and consumer rights movements can be integrated and updated within the context of data activism. The introductory section provides the background for the main arguments of the article. The method of this work is critical reflection and a theoretical discussion supported by a survey of a set of relevant research papers.
\end{abstract}

Keywords: Big data, surveillance, data activism, critical citizenship education, consumer rights movement 


\section{EXTENDED ABSTRACT}

Our era of surveillance capitalism is characterized by pervasive rather than targeted surveillance. Currently, the big brother is not watching the dissidents but everybody for a tiny probability of disobedience. In the past there were mainly two kinds of surveillance: Physical chase which means undercover agents following the target anti-government figures in person and technical chase which mostly corresponds to phone taps. However nowadays there is no need for physical chase, as technical chase replaced it and expanded the areas and 'opportunities' of surveillance through ubiquitous surveillance devices including CCTVs, mobile tracking, net tracking etc.

Citizenship education offered in schools that can form the basis of antisurveillance activism is usually from the governments' perspective. A critical sense of citizenship is rarely promoted in these official contexts. Thus, acquisition of critical citizenship consciousness is usually through peer learning at informal and nonformal settings. In many countries, adults and especially young adults join protests, and usually they acquire citizenship education skills and knowledge in a blended way whereby offline and online political activisms support each other. Thus ICTs usually utilized for entertainment are educationalized to serve the pedagogical interests of the citizens. They learn more on social media about citizenship education than the formal citizenship education courses.

We should reflect on informal and non-formal forms of critical citizenship education via ICTs including but not only limited to social media platforms. We propose that in order not to formalize and institutionalize citizens' actively acquired critical citizenship skills and knowledge, the disconnect between formal non-critical, official forms of citizenship education and informal, non-formal, blended and citizen-based critical citizenship education should continue. Under the funding of governments or corporations, the criticality of citizenship education will be limited. That is why, citizens should support and develop their own citizenship initiatives and resources in both online and offline settings. The citizen and consumer rights movements are the perfect matches for such an endeavor.

In the case of activist uses of social media, a remarkable point is the fact that most of the Internet users voluntarily release personal information on the web. They are 
fulfilling their needs for recognition, reputation, socialization etc. Thus, activist use of social media should be able to identify the motivations behind voluntary release of personal information and be cautious about what to share and not to share on social media. This brings up the notion of social media literacy. However, since social media literacy is not necessarily critical, as it may develop on the basis of conservative reactions to the corruption of traditional society by the influence of computers and internet, this literacy should be critical. Hence we have the term 'critical social media literacy' as a better match.

Even under ubiquitous surveillance capitalism, either through literacies or by other means, we should still find the ways to resist. Citizen data activism can be about surveilling the corporate surveillers themselves. Data activist citizens can feed a website with corporate surveillance practices that they find unethical. Unlike the government who justifies surveillance on the basis of security, corporations have no excuse for surveilling other than maximizing profits. Under pre-big-data capitalism, a number of initiatives were successful to protect and promote consumer rights. For citizen data activism, those websites need upgrades to surveil the surveillers.

Citizen data activism should be in close collaboration with citizen science movements which capitalize on crowdsourcing for scientific purposes. We need to develop alternatives to surveillers by collecting and interpreting our own data -to break'the monopoly of interpretation' as stated previously.

We urge data activists and rights movements to unite their forces for mutual benefit. The search on Google Scholar for 'data activism' and 'consumer rights' bring out almost no results. Same holds for 'data activism' and 'rights movements', and for 'data activism' and 'social solidarity', while a higher number of results are listed for 'data activism' and 'human rights' although the number is far from satisfactory considering the possible links between the two. This picture clearly shows that the links mentioned here are uncharted and understudied.

To conclude, the resistance against big data, the new big brother is not in vain and neither hopeless. Instead, there are potentials not even utilized and links not considered. Through this article on data activism, our hope has been to show a way of resistance to be argued, elaborated on and ultimately evaluated in terms of its merits and demerits by the decision makers of the rights movements. 


\section{INTRODUCTION}

How can citizenship education and consumer rights movements be integrated and upgraded with regard to data activism? Such a question inevitably direct us into various issues related to the notion of data. Thus, to discuss data activism, we need a brief introduction to the notion of big data. In this paper, we will go into the details of the notions of big data, digital activism, surveillance, critical citizenship education and consumer rights to come up with an integrated approach. The method endorsed in this work is critical reflection coupled with theoretical discussions supported by various research papers on the subject. The topic of this article is important as the rise of big data brings not only opportunities but also social problems. These social problems pave the way for resistance and activism.

As a first step, we try to prepare the intellectual background for our discussion of data activism.

For Lewis \& Westlund (2014, p. 1):

...big data is a social, cultural, and technological phenomenon-a complex amalgamation of digital data abundance, emerging analytic techniques, mythology about data-driven insights, and growing critique about the overall consequences of big-data practices for democracy and society.

As elaborately stated by the authors (Lewis \& Westlund, 2014), big data is intricately linked with democracy. This link can be traced back to the data collection and recording processes: In fact, as pointed out by Baack (2015), raw data can be better be conceived as oxymoron, since the way data are collected is also based on interpretation, a conclusion reached by Rajão \& Jarke (2018) following their research on environmental data transparency about Amazon forests and deforestation. This interpretation can be emanating from human collectors or human designers who designed non-human collectors. The way they design the devices is also based on interpretation. The link between big data and democracy is also visible at the post-collection process as stated by Gurin $(2015$, p. 691): 
The impact of data depends not only on how much data exists about a particular area, population, or individual, but how open the data is, who has access to it, and how it can be used to meet social or economic goals.

Gurin converges with Hansson, Belkacem \& Ekenberg $(2015$, p. 11) who state that "we need a more critical discussion on who controls the data, how the data are produced, and by whom."

In that sense, for Gurin (2015, p. 692), the notions of big data and open data are intricately linked with each other:

Big Data is most useful, and has the greatest economic and social value, when it is also Open Data. By releasing Big Data as Open Data, governments around the world can boost their countries' economies and improve the lives of their citizens.

So this approach claims that big data are not problematic per se, their nonopenness, misuses and abuses cause the real problem. There may be, the argument goes, benevolent uses of big data. Of course, ideally this could be possible; but the reality is different. For one thing, big data is not properly collected abiding to the scientific principles. It is subject to recording and measurement errors, and biases on the unintentional side, and distortions and manipulations on the intentional side. Thus, not only at post-production, but even at pre-production stage of big data generation, we need to be data-skeptic. This skepticism also questions the citizen data movement (Gabrys, Pritchard \& Barratt, 2016) although not completely rejecting it, as the devices to collect data by citizens are usually designed for governmental and/or corporate interests rather than scientific purposes.

Another criticism of mainstream studies of big data is geographical and cultural: Milan \& Trere (2017) question the West-centricity of Big Data discussions. Big data is usually discussed with globally Western assumptions, however majority of the world population lives in the global South where people are mostly 'underconnected' and 'under-datafied'. Arora (2016) warns that with a neoliberal outlook, big-datafication leads to marketization and consumerization of the poor in the global South. Furthermore, global North-origined big data projects applied in the global South has colonial implications which points out the need for indigenization of these projects (Arora, 2016). 


\section{Snowden Revelations and Evolution of State Surveillance}

Surveillance capitalism is not without its predecessors; activists are well aware of state surveillance over anti-government and anti-capitalist movements before the advent of big data (Dencik, Hintz \& Cable, 2016), however current policies differ from previous ones in a number of points: For one thing, in the past there were mainly two kinds of surveillance: Physical chase which means undercover agents following the target anti-government figures in person and technical chase which mostly corresponds to phone taps. However nowadays there is no need for physical chase, as technical chase replaced it and expanded the areas and 'opportunities' of surveillance through ubiquitous surveillance devices including CCTVs, mobile tracking, net tracking etc. In some cases, old methods are still employed together with the new methods (Dencik et al., 2016). Secondly, the big brother is not watching the dissidents but everybody for a tiny probability of disobedience. The most typical example of this is practiced in China in the name of the social credit system, whereby governments and corporations rate citizen-user-consumers on the basis of their political behavior and shopping habits (see Creemers, 2018; Kotska, 2018).

In his study on how Iranian government implements digital surveillance against Iranian activists and journalists abroad, Michaelsen (2017) shows that unlike the geographical boundaries, governments are unbounded on Internet. They can interfere with anybody living out of the borders of the state. Not only Iranian government but all surveillant states are known to act transnationally. Furthermore, Snowden revelations show that the line between public and private surveillers is blurred (Zuboff, 2015). There is no secure line or channel not surveilled.

According to Pohle \& Van Audenhove (2017, p. 2), Snowden revelations

...provide insights into a wide network of surveillance tools, programmes and actors covering at least three different dimensions: Firstly, they revealed the scale and extent of surveillance, meaning the massive quantity of the collected data and the vast number of people who are being systematically surveilled; secondly, they provide extensive information about the kind of data that is being intercepted and collected, ranging from metadata (i.e. who communicated with whom and when) to 
the content of phone calls and emails; and thirdly, they reveal the actual practices of surveillance, i.e. the different programmes and cooperation mechanisms that allow for the vastness of surveillance in place and the integration and processing of the collected data.

It was shocking to see that heads of presidents of various countries were tapped as well (Pohle \& Van Audenhove, 2017), whether this was able to be stopped is a moot question. Post-Snowden legislation, Pohle \& Van Audenhove (2017) rightly claim, rather than condemning and disabling big-brother style surveillance legalized extreme forms of surveillance for state interests, a view also shared by Hintz \& Dencik (2016). In that sense, Barnhizer (2013) uses the term 'post-democratic electronic state' to identify this new type of government exposed by Snowden revelations.

However, the media characterization of the surveilling state was lopsided: Hintz \& Dencik (2016, p. 9) notice that "surveillance of political leaders, such as revelations regarding spying on Angela Merkel, was scandalised whereas mass surveillance of citizens was treated with significantly less urgency." This intentionally or unintentionally implies that some of the citizens including Merkel should be exempted from surveillance, but it is fine with others. In fact, this is what is meant by the notions of 'data injustice' and 'data discrimination'.

Taylor (2017, p. 1) defines 'data justice' as "fairness in the way people are made visible, represented and treated as a result of their production of digital data" and accordingly proposes the notion of data discrimination. She presents a case from India where more than a billion people are datafied for fair welfare entitlements for the poorest, but because of the way the data are collected, the target group to serve is in fact excluded. ${ }^{2}$

"(In)visibility, (dis)engagement with technology and antidiscrimination" are listed as the pillars of data justice (Taylor, 2017, p.1). However, such a conceptualization of the problem implies that some people deserve digital mistreatment, some people don't, as justice systems usually depend on punishment. That is why, a better characterization would be 'data democracy'. Thus, not only Merkel but any other citizen should have the rights and protection against unethical forms of surveillance. 
Steinfeld (2017) finds that Israeli people don't consider state surveillance and corporate surveillance as a single phenomenon. They distinguish the two. Although they support state surveillance for security reasons, they are not in favor of surveillance in general. They are even less willing to be surveilled by corporations. We will talk about this in the upcoming pages.

\section{Digital Activism and Data Activism}

For activists witnessing or directly experiencing former forms of surveillance, Snowden revelations were not surprising at all (Dencik et al., 2016). It was just like a confirmation of a something well-known. That is why, according to the findings of Dencik and his colleagues (2016), the revelations were not transformative for activists. Thus anti-surveillance measures implemented by the activists were limited. According to Dencik and Cable (2017), this corresponds to the notion 'surveillance realism': People realize that surveillance is inevitable, thus they accept it as a reality. In that sense, surveillance is normalized.

George and Leidner (2018) briefly define digital activism as "the appropriation of information systems (IS) to enact political action" (p. 2300). According to them, digital activism corresponds to political uses of social media on the one hand, and hacking on the other. They further classify hacking into three: "hacktivists, civic hackers, and patriotic hackers" (p. 2301).

George and Leidner (2018) classify digital activism through a hierarchy based on effort. Clicktivism (also known as slacktivism) and registering a view are low effort activities, funding a cause and political consumerism (e.g. boycotting vs. supporting a company on a political basis) as medium effort activities, while data activism, information exposure (e.g. Wikileaks) and hacktivism are considered to be high effort activities. Low to medium effort activities require participation of a high number of people for impact and limited set of IT skills, for medium to high effort activities even a single activist such as a hacker would be sufficient, but they require an advanced set of IT skills such as ability to DDOS attack.

According to George and Leidner (2018), data activism "is triggered when closed governments refuse to share data or when open government is threatened by the removal of open data" (p. 2304); "it examines, manipulates, leverages and 
takes advantage of existing data, but also resists and meddles data creation and use-and these tactics can be seen as antiprograms to pre-set hegemonic uses of data and software" (Milan, 2016, p.16).

Somewhat converging with George and Leidner (2018), Milan \& Van Der Velden $(2016$, p. 57) identify 2 kinds of data activism which are considered to be on a continuum rather than discrete categories: Pro-active data activism ("ways of affirmative engagement with data", "data-based advocacy") and reactive data activism ("tactics of resistance to massive data collection", "encryption practices"). According to Milan and Gutiérrez (2015, pp. 122-123):

Re-active data activism comprises the practices of resistance to the threats to civil and human rights that derive from corporate and government privacy intrusion. Pro-active data activism embraces those individuals and civil society organizations that take advantage of the possibility for social change and civic engagement offered by big data.

Ekbia and his colleagues (2015, p. 1540) state that "disparities between the haves and have-nots are already visible between major technology companies and their users, between government and citizens, and between large and small businesses and universities, giving rise to what can be called the 'data divide."' Open data activists and their activities try to break the 'interpretative monopoly of governments' over raw data and believe in the need to transform journalism to become a democratic intermediary between the raw data and the public by blending with citizen journalism (Baack, 2015).

From a Marxist point of view, data collection, processing and interpretation tools can be considered as the means of production by which we can take account of information inequalities. While corporate surveillance fits this idea directly, government surveillance contributes to capital accumulation indirectly. Corporate surveillance leads to more profit, while government surveillance is not for profit, but to secure the status quo that favors profit makers. That is why, the ownership of the means of production in this case (i.e. data collection, processing and interpretation tools as stated above) divide people into a tiny percentage of data elites or data patricians and data publics or data plebeians. 
In this context, we can talk about data alienation which refers to the fact that we have no control of our data as we don't own data collection, processing and interpretation tools, although we are the producers of data. However, a significant difference between pre-big-data capitalism and big data capitalism would be in the fact that not only the working class but everybody produces data, including surveillers themselves. Production is deterritorialized in big data capitalism, it is not confined to factories. This one more time shows that what we term as 'data rights' is not a matter of a section of the society such as the working class only nor a group of educated people such as active internet users. It should go hand in hand with citizenship rights.

\section{Data Activism and Critical Citizenship Education}

Citizenship education offered in schools is usually from the governments' perspective. A critical sense of citizenship is rarely promoted in these official contexts. Thus, acquisition of critical citizenship consciousness is usually through peer learning at informal and non-formal settings. ${ }^{3}$ In many countries, adults and especially young adults join protests, and usually they acquire citizenship education skills and knowledge in a blended way whereby offline and online political activisms support each other. Thus ICTs usually utilized for entertainment are educationalized to serve the pedagogical interests of the citizens. They learn more on social media about citizenship education than the formal citizenship education courses.

Converging with this, Chu (2018) points out the disconnect between the official citizenship education and students' online and offline activism within the context of Hong Kong's Umbrella Movement. While the former is apolitical and bookish, the latter involves alternative accounts of political events. A similar observation is shared by Tupper (2014) in the case of activism about indigenous people's rights in Canada, where pedagogical potential of blended political campaigns are discussed. The situation is not different in Europe either according to Biesta (2009). It is observed that European formal citizenship education does not promote civic activism (Biesta, 2009). In the same vein, Ribeiro and her colleagues (2012, p. 32) conclude that

Results suggest that the vision of CE [Citizenship Education] as a priority in educational policy documents is questioned by NGOs that consider [that] schools 
are too focused on formal democracy and overemphasize respect for rules, values and responsibilities, rather than promoting critical, informed and active citizens. Especially in countries with an authoritarian past, NGOs consider that models of conformism and submission are still dominant, and emphasize the role of CE in promoting a strong civil society.

On the other hand, it is noteworthy to see that unlike the common sense view, social media use does not boost political engagement, as those using social media for political purposes are the ones that are already political in their real lives (Keating \& Melis, 2017). Kara's (2018, p. 172) findings are even more pessimistic: "students indicated that they do not prefer to engage in political activities online because of emotional disturbance, pressure from society, and a fear of affecting their future lives in a negative way." Nevertheless, from another research tradition, Chee, Mehrotra, \& Liu (2013) and San Chee, Tan \& Liu (2010) describe and discuss the uses of a computer game (Statecraft) to promote citizenship education. In other studies (e.g. Lim, 2008; Lim \& Ong, 2012), other video games and 'multiuser virtual environments' are presented and discussed for the same purpose. ${ }^{4}$

We should reflect on informal and non-formal forms of critical citizenship education via ICTs including but not only limited to social media platforms. We propose that in order not to formalize and institutionalize citizens' actively acquired critical citizenship skills and knowledge, the disconnect between formal non-critical, official forms of citizenship education and informal, non-formal, blended and citizenbased critical citizenship education should continue. Under the funding of governments or corporations, the criticality of citizenship education will be limited. That is why, citizens should support and develop their own citizenship initiatives and resources in both online and offline settings. The citizen and consumer rights movements are the perfect matches for such an endeavor.

\section{Data Democracy and Democratization of Data}

The most typical metaphor associated with big data is Foucault's panopticon, but

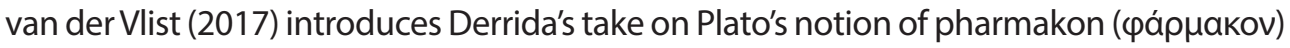
both as a cure (tools of resistance and hopefully emancipation) and poison (tools of exploitation). Ekbia et al. (2015, p. 1540) formulate a similar position although without mentioning the notion of pharmakon: "Digital technologies have a dual characterempowering, liberating, and transparent, yet also intrusive, constraining, and opaque." 
In fact this double meaning is also reflected in the notion of 'drugs' in English language whereby both medicine and addictive chemicals are meant. Of course, this double interpretation has been very common in science, technology and society research and related areas ${ }^{5}$ in which a knife is said to be used for peeling fruits or stabbing, but such a characterization of big data needs further discussion, as the resistance and emancipatory side of the coin is less visible and influential compared to the exploitative side. We have the control over the knife if not in its design, while that is not the case with the big data. Even open data would be useless without democratic devices of data processing and interpretation. So maybe this analogy is not applicable for big data at all in the current course of events.

Contrary to those who assigned an emancipatory role to digital technologies, based on their case study, Treré $(2016$, p. 127) concludes that they are instead used "to manufacture consent, sabotage dissidence, threaten activists, and gather personal data without citizens' agreement." Thus, contrary to the initial expectations, digital technologies were quickly dominated and controlled by authoritarian governments to suppress dissent (Treré, 2017).

Gray (2015) argues that one way to democratize the so-called 'data revolution' is supporting initiatives that record certain cases that are not recorded by the authorities such as the number of refugees drown on their way to reach Europe (which corresponds to the 'Migrants Files' project) or cases of police brutality (or specifically number of deaths under custody matching the 'Counted' project). Another way, Gray (2015) argues, is by opening already collected data by the authorities to the public, in the spirit of the open data movement. A more radical approach is in favor of data leaking is it helps anti-corruption campaigns and democratization accordingly (Mattoni, 2017). Although Wikileaks is the first to come to mind, there are many other cases at national and local levels which led to resignation of incumbent politicians e.g. in Italy and Spain (Mattoni, 2017). ${ }^{6}$

In the case of activist uses of social media, a remarkable point is the fact that most of the Internet users voluntarily release personal information on the web. Romele et al. (2017) consider this as an act of voluntary servitude, where people are willingly enslaved. However, from a broader perspective, people are sharing these with certain expectations and/or actual returns. They are fulfilling their needs for recognition, reputation, socialization etc. Thus, activist use of social media should be able to identify 
the motivations behind voluntary release of personal information and be cautious about what to share and not to share on social media. This brings up the notion of social media literacy. However, since social media literacy is not necessarily critical, as it may develop on the basis of conservative reactions to the corruption of traditional society by the influence of computers and internet, this literacy should be critical. Hence we have the term 'critical social media literacy' as a better match. On the other hand, data are categorically different than social media shares. When a user intentionally or unintentionally produce data, s/he has no expectation of return and/or actual return.

In that sense a relevant term has been proposed by Pybus, Coté and Blanke (2015, p. 4):

Data literacy can act as an extension and updating of traditional discourses around media literacy by refocusing our attention to the material conditions that surround a user's data within highly proprietary digitised environments. Given the growing imbalance between those who produce data and those who produce value from that data, there is a need to open up new forms of digital literacies, such as privacy literacies, information literacies, code literacies, algorithmic literacies, database literacies and so forth.

Gray, Gerlitz and Bounegru (2018, p. 1) propose a more refined, complementary term:

We argue for an expansion of the concept to include not just competencies in reading and working with datasets but also the ability to account for, intervene around and participate in the wider socio-technical infrastructures through which data is created, stored and analysed - which we call "data infrastructure literacy."

Even under ubiquitous surveillance capitalism, either through literacies or by other means, we should still find the ways to resist. Hintz and Dencik (2016, p. 8) point out that

Technology activists have developed anonymisation tools such as the Tor browser, advanced the incorporation of strong encryption in email and other online data exchanges, offered self-organised and privacy-enhanced internet services such as riseup. net, and experimented with various methods of obfuscation in digital environments.

With the same idea in mind, Hogan and Shepherd (2015) recommend two solutions against this big data capitalism: The first is the local storage of data, while 
the second is the consideration of offline modalities. Hogan and Shepherd (2015) remind us that Brazilian proposal to Google, Facebook and others to store the data on servers within Brazil was a viable option. However, local servers can also be surveilled (Hogan \& Shepherd, 2015). Thus, so far, no technical panacea is proposed against surveillance.

Nevertheless, data resistance and activism are not in vain. As Steinfeld (2017)'s research shows, corporate surveillance is an easier target. So we can start a citizen data activism movement against this kind of surveillance. Citizen data activism can be about surveilling the corporate surveillers themselves. Data activist citizens can feed a website with corporate surveillance practices that they find unethical. Such cases can be collected to organize campaigns and especially boycott the surveillers which corresponds to George and Leidner (2018)'s mid-level data activism on the basis of activists' effort, as explained previously. Unlike the government who justifies surveillance on the basis of security, corporations have no excuse for surveilling other than maximizing profits. Under pre-big-data capitalism, a number of initiatives were successful to protect and promote consumer rights. An example is Consumer Reports organization. ${ }^{7}$ For citizen data activism, those websites need upgrades to surveil the surveillers.

Citizen data activism should be in close collaboration with citizen science movements which capitalize on crowdsourcing for scientific purposes. An example for citizen science is Zooniverse ${ }^{8}$ which was originally established to crowdsource scanning of nearly a million telescopic images in search for galaxies, stars, planets, satellites etc. We need to develop alternatives to surveillers by collecting and interpreting our own data -to break'the monopoly of interpretation' as stated previously.

\section{DISCUSSION AND CONCLUSION}

In this article, we presented some of the prominent research works on big data, surveillance and data activism. We hope and expect that data activism would be popularized to be a default item of every citizens' informational toolbox. This situation is analogous with the advent of Internet. In 1990s, Internet had been considered to be a technical matter closed to 'uneducated' public. Initially it had seemed that only those with high level of technical skills could use it. However, by the $21^{\text {st }}$ century the situation is different, with Internet popularized to become simpler than initially 
expected. However this analogy is contingent: A major factor behind popularization of Internet was the invention and marketization of user-friendly designs. Likewise, rights movements including both citizens' and consumers' should collaborate with data activists to develop activist-friendly designs. With such a collaboration, popularization and especially crowdsourcing, data activism will be stronger than ever. Although there is no perfect cure for surveillance and other malpractices of the so-called 'post-democratic electronic state', such an integration between rights movements and data activism will definitely contribute to democratization of data, and the ultimate goal of data democracy. An alternative to this proposal would be the development of a data rights movement inspired by the Pirates Party. However, a rights movement only focusing on data has low chances of success. Again and again, data activism needs to be integrated with other forms of activism.

Thus, we urge data activists and rights movements to unite their forces for mutual benefit. The search on Google Scholar for 'data activism' and 'consumer rights' bring out almost no results. Same holds for 'data activism' and 'rights movements', and for 'data activism' and 'social solidarity', while a higher number of results are listed for 'data activism' and 'human rights' although the number is far from satisfactory considering the possible links between the two. One can review just a few publications (e.g. Milan, 2016; Milan \& Gutiérrez, 2015; Milan, \& Van Der Velden, 2016) for a generic, introductory discussion of the matter; but we need more detailed and comprehensive reflections on these links. This picture clearly shows that the links mentioned here are uncharted and understudied.

Before concluding our discussion we should also keep mind that research on data activism is mostly on the Global West and the Global North. To balance and extend the arguments, the upcoming work from other regions of the world will be vital (e.g. Arora, 2019; Chenou \& Cepeda-Másmela, 2019; Meng et al., 2019; Milan \& Treré, 2019; Segura \& Waisbord, 2019).

To conclude, the resistance against big data, the new big brother is not in vain and neither hopeless. Instead, there are potentials not even utilized and links not considered. Through this article on data activism, our hope has been to show a way of resistance to be argued, elaborated on and ultimately evaluated in terms of its merits and demerits by the decision makers of the rights movements. 


\section{ENDNOTES}

1. In this context, we also need to talk about the notion of dataveillance. Degli Esposti (2014) defines dataveillance as "the systematic monitoring of people or groups, by means of personal data systems in order to regulate or govern their behavior" (p. 209). However, we prefer not to use this term in this article: That is because we think that the use of this term just lightens the onus of the surveilling governments and corporations. The term helps them to look like more innocent: Rather than watching the citizens, they are wrongly claimed to watch the data only, which can be considered as a minor problem. However, they track data to collect information about the citizens. So the data is not the end point for surveiller, they are proxies. In that sense, they are not really watching the data; instead they watch citizens via data.

2. However, we need to be careful about orientalizing poverty, in other words studying poverty as a nonWestern problem. Madden et al. (2017), based on a survey study describe various ways through which American poor are digitally discriminated.

3 For the distinction among formal, informal and non-formal types of education see Colardyn \& Bjornavold, 2004; Eraut, 2000; Greenhow \& Lewin, 2016.

4. However, let us note that a video game study funded by the government will be categorically different in its content of citizenship education, usually lacking comprehensive critical skills.

5. E.g. De Ville, 2010; Kern, 2014; and McCaffrey, 2016.

6. In fact, this form of data activism is not without precedents: E.g. even on an early year such as 1997, a high school principal had to resign due to a computer-savvy student who remotely hacked the principal's computer to expose corruption. Earlier forms of non-activist hacker activity can be noted as well, but politically or socially motivated hacking (i.e. hacktivism) had emerged at a later date (cf. Goode, 2015; Jordan, 2007; Morva, 2013; Polat, Bakıroğlu \& Sayın, 2013).

7. https://www.consumerreports.org/cro/about-us/what-we-do/index.htm

8. For more details see Bonney et al., 2014; Cox et al., 2015; Newman et al., 2012. 


\section{REFERENCES}

Arora, P. (2019). Decolonizing privacy studies. Television \& New Media, 20(4), 366-378.

Arora, P. (2016). Bottom of the data pyramid: Big data and the global south. International Journal of Communication, 10, 1681-1699.

Baack, S. (2015). Datafication and empowerment: How the open data movement re-articulates notions of democracy, participation, and journalism. Big Data \& Society, 2(2), 1-11. http://dx.doi.org/ $10.1177 / 2053951715594634$

Barnhizer, D. (2013). Through a prism darkly: Surveillance and speech suppression in the 'post-democracy electronic state'. Retrieved from http://docshare01.docshare.tips/files/17756/177568199.pdf

Biesta, G. (2009). What kind of citizenship for European higher education? Beyond the competent active citizen. European Educational Research Journal, 8(2), 146-158.

Bonney, R., Shirk, J. L., Phillips, T. B., Wiggins, A., Ballard, H. L., Miller-Rushing, A. J., \& Parrish, J. K. (2014). Next steps for citizen science. Science, 343(6178), 1436-1437.

Chee, Y. S., Mehrotra, S., \& Liu, Q. (2013). Effective game based citizenship education in the age of new media. Electronic Journal of e-Learning, 11(1), 16-28.

Chenou, J. M., \& Cepeda-Másmela, C. (2019). \# NiUnaMenos: Data Activism From the Global South. Television \& New Media, 20(4), 396-411. http://dx.doi.org/10.1177/1527476419828995

Chu, D. S. (2018). Media Use and Protest Mobilization: A Case Study of Umbrella Movement Within Hong Kong Schools. Social Media+Society, 4(1), 1-11.

Colardyn, D., \& Bjornavold, J. (2004). Validation of Formal, Non-Formal and Informal Learning: policy and practices in EU Member States 1. European Journal of Education, 39(1), 69-89.

Cox, J., Oh, E. Y., Simmons, B., Lintott, C., Masters, K., Greenhill, A., Graham, G. \& Holmes, K. (2015). Defining and measuring success in online citizen science: A case study of Zooniverse projects. Computing in Science \& Engineering, 17(4), 28-41.

Creemers, R. (2018). China's Social Credit System: An evolving practice of control. Retrieved from http://www. iberchina.org/files/2018/social_credit_china.pdf

De Ville, J. (2010). Revisiting Plato's Pharmacy. International Journal for the Semiotics of Law-Revue Internationale de Sémiotique Juridique, 23(3), 315-338.

Degli Esposti, S. (2014). When big data meets dataveillance: The hidden side of analytics. Surveillance \& Society, 12(2), 209.

Dencik, L., \& Cable, J. (2017). The advent of surveillance realism: Public opinion and activist responses to the Snowden leaks. International Journal of Communication, 11, 763-781.

Dencik, L., Hintz, A., \& Cable, J. (2016). Towards data justice? The ambiguity of anti-surveillance resistance in political activism. Big Data \& Society, 3(2), 1-12. https://dx.doi.org/10.1177/2053951716679678 
Ekbia, H., Mattioli, M., Kouper, I., Arave, G., Ghazinejad, A., Bowman, T., ... \& Sugimoto, C. R. (2015). Big data, bigger dilemmas: A critical review. Journal of the Association for Information Science and Technology, 66(8), 1523-1545.

Eraut, M. (2000). Non-formal learning and tacit knowledge in professional work. British Journal of Educational Psychology, 70(1), 113-136.

Gabrys, J., Pritchard, H., \& Barratt, B. (2016). Just good enough data: Figuring data citizenships through air pollution sensing and data stories. BigData \& Society, 3(2), 1-14. https://dx.doi.org/10.1177/2053951716679677

George, J., \& Leidner, D. (2018). Digital Activism: a Hierarchy of Political Commitment. Retrieved from https:// scholarspace.manoa.hawaii.edu/bitstream/10125/50176/1/paper0289.pdf

Goode, L. (2015). Anonymous and the political ethos of hacktivism. Popular Communication, 13(1), 74-86.

Gray, J. (2015). Democratising the Data Revolution: A Discussion Paper. Retrieved from https://assets.okfn.org/ files/reports/DemocratisingDataRevolution.pdf

Gray, J., Gerlitz, C., \& Bounegru, L. (2018). Data infrastructure literacy. Big Data \& Society, 5(2), 1-13. https://dx.doi. org/10.1177/2053951718786316

Greenhow, C., \& Lewin, C. (2016). Social media and education: reconceptualizing the boundaries of formal and informal learning. Learning, Media and Technology, 41(1), 6-30.

Gurin, J. (2014). Big Data and Open Data: How Open Will the Future Be. I/S: A Journal of Law and Policy for the Information Society, 10(3), 691-704.

Hansson, K., Belkacem, K., \& Ekenberg, L. (2015). Open government and democracy: A research review. Social Science Computer Review, 33(5), 540-555.

Hintz, A., \& Dencik, L. (2016). The politics of surveillance policy: UK regulatory dynamics after Snowden. Internet Policy Review, 5(3), 1-16.

Hogan, M., \& Shepherd, T. (2015). Information ownership and materiality in an age of big data surveillance. Journal of Information Policy, 5, 6-31.

Jordan, T. (2007). Online direct action: Hacktivism and radical democracy. In Radical democracy and the internet (pp. 73-88). Palgrave Macmillan, London.

Kara, N. (2018). Understanding University Students'Thoughts and Practices about Digital Citizenship: A Mixed Methods Study. Journal of Educational Technology \& Society, 21(1), 172-185.

Keating, A., \& Melis, G. (2017). Social media and youth political engagement: Preaching to the converted or providing a new voice for youth?. The British Journal of Politics and International Relations, 19(4), 877-894.

Kern, R. (2014). Technology as Pharmakon: The promise and perils of the internet for foreign language education. The Modern Language Journal, 98(1), 340-357.

Kotska, G. (2018). China's social credit systems and public opinion: Explaining high levels of approval. Retrieved from https://www.researchgate.net/profile/Genia_Kostka

Lewis, S. C., \& Westlund, O. (2015). Big data and journalism: Epistemology, expertise, economics, and ethics. Digital journalism, 3(3), 447-466. 
Lim, C. P. (2008). Global citizenship education, school curriculum and games: Learning Mathematics, English and Science as a global citizen. Computers \& Education, 51(3), 1073-1093.

Lim, K. Y., \& Ong, M. Y. (2012). The Rise of Li'Ttledot: A study of citizenship education through game-based learning. Australasian Journal of Educational Technology, 28(8), 1420-1432.

Madden, M., Gilman, M., Levy, K., \& Marwick, A. (2017). Privacy, poverty, and Big Data: A matrix of vulnerabilities for poor Americans. Washington University Law Review, 95(1), 53-125.

Mattoni, A. (2018). From data extraction to data leaking. Data-activism in Italian and Spanish anti-corruption campaigns. Partecipazione e Conflitto, 10(3), 723-746.

McCaffrey, G. (2016). Compassion, Necessity, and the Pharmakon of the Health Humanities. Journal of Applied Hermeneutics. Retrieved from https://journalhosting.ucalgary.ca/index.php/jah/index

Meng, A., DiSalvo, C., Tsui, L., \& Best, M. (2019). The social impact of open government data in Hong Kong: Umbrella Movement protests and adversarial politics. The Information Society, 35(4), 216-228. https://dx.doi. org/10.1080/01972243.2019.1613464

Michaelsen, M. (2017). Far Away, So Close: Transnational Activism, Digital Surveillance and Authoritarian Control in Iran. Surveillance \& Society, 15(3/4), 465-470.

Milan, S. (2016). Data activism as the new frontier of media activism. Retrieved from http://www.academia.edu/ download/40974104/media-activism-chapter-v2-SENT.pdf

Milan, S., \& Gutiérrez, M. (2015). Citizens' media meets big data: The emergence of data activism. Mediaciones, 11(14), 120-133.

Milan, S., \& Treré, E. (2019). Big Data from the south (s): Beyond data universalism. Television \& New Media, 20(4), 319-335.

Milan, S., \& Trere, E. (2017). Big Data from the South: The Beginning of a Conversation We Must Have. Retrieved from http://www.academia.edu/download/54804190/BigDatafromtheSouth-SSRN.pdf

Milan, S., \& Van Der Velden, L. (2016). The alternative epistemologies of data activism. Digital Culture \& Society, 2(2), 57-74.

Morva, O. (2013). An alternative way of political criticism: the Redhack team as a case study for hacktivism. In Breaking the media value chain. VII International Conference on Communication and Reality (pp. 477-484). Facultat de Comunicació Blanquerna.

Newman, G., Wiggins, A., Crall, A., Graham, E., Newman, S., \& Crowston, K. (2012). The future of citizen science: emerging technologies and shifting paradigms. Frontiers in Ecology and the Environment, 10(6), $298-304$.

Pohle, J., \& Van Audenhove, L. (2017). Post-Snowden internet policy: between public outrage, resistance and policy change. Media and Communication, 5(1), 1-6.

Polat, B., Bakıroğlu, C. T., \& Sayın, M. E. D. (2013). Hactivism in Turkey: the case of Redhack. Mediterranean Journal of Social Sciences, 4(9), 628-636.

Pybus, J., Coté, M., \& Blanke, T. (2015). Hacking the social life of Big Data. Big Data \& Society, 2(2), 1-10. https:// dx.doi.org/10.1177/2053951715616649 
Rajão, R., \& Jarke, J. (2018). The materiality of data transparency and the (re) configuration of environmental activism in the Brazilian Amazon. Social Movement Studies, 17(3), 318-332.

Ribeiro, A. B., Rodrigues, M., Caetano, A., Pais, S., \& Menezes, I. (2012). Promoting" Active Citizens"? The Critical Vision of NGOs over Citizenship Education as an Educational Priority across Europe. International Journal of Progressive Education, 8(3), 32-47.

Romele, A., Gallino, F., Emmenegger, C., \& Gorgone, D. (2017). Panopticism is not Enough: Social Media as Technologies of Voluntary Servitude. Surveillance and Society, 15(2), 204-221.

San Chee, Y., Tan, E. M., \& Liu, Q. (2010, April). Statecraft X: Enacting citizenship education using a mobile learning game played on Apple iPhones. In Wireless, Mobile and Ubiquitous Technologies in Education (WMUTE), 2010 6th IEEE International Conference on (pp. 222-224). IEEE.

Segura, M. S., \& Waisbord, S. (2019). Between Data Capitalism and Data Citizenship. Television \& New Media, 20(4), 412-419. https://dx.doi.org/10.1177/1527476419834519

Steinfeld, N. (2017). Track me, track me not: Support and consent to state and private sector surveillance. Telematics and Informatics, 34(8), 1663-1672.

Taylor, L. (2017). What is data justice? The case for connecting digital rights and freedoms globally. Big Data \& Society, 4(2), 1-14. https://dx.doi.org/10.1177/2053951717736335

Treré, E. (2017). Distorsiones tecnopolíticas: represión y resistencia algorítmica del activismo ciudadano en la era del big data. Trípodos, 39, 35-51.

Treré, E. (2016). The dark side of digital politics: Understanding the algorithmic manufacturing of consent and the hindering of online dissidence. IDS Bulletin, 47(1), 127-138.

Tupper, J. (2014). Social Media and the Idle No More Movement: Citizenship, Activism and Dissent in Canada. Journal of Social Science Education, 13(4), 87-94.

van der Vlist, F. N. (2017). Counter-Mapping Surveillance: A Critical Cartography of Mass Surveillance Technology After Snowden. Surveillance \& Society, 15(1), 137-157.

Zuboff, S. (2015). Big other: surveillance capitalism and the prospects of an information civilization. Journal of Information Technology, 30(1), 75-89. 